\title{
Control of prostate cancer associated with withdrawal of a supplement containing folic acid, L-methyltetrahydrofolate and vitamin $\mathrm{B}_{12}$ : a case report
}

\author{
Glenn Tisman* and April Garcia
}

\begin{abstract}
Introduction: This is the first report of possible direct stimulation of hormone-resistant prostate cancer or interference of docetaxel cytotoxicity of prostate cancer in a patient with biochemical relapse of prostatic-specific antigen. This observation is of clinical and metabolic importance, especially at a time when more than 80 countries have fortified food supplies with folic acid and some contemplate further fortification with vitamin $B_{12}$.

Case presentation: Our patient is a 71-year-old Caucasian man who had been diagnosed in 1997 with prostate cancer, stage T1c, and Gleason score 3+4 $=7$. His primary treatment included intermittent androgen deprivation therapy including leuprolide + bicalutamide + deutasteride, ketoconazole + hydrocortisone, nilandrone and flutamide to resistance defined as biochemical relapse of PSA. While undergoing docetaxel therapy to treat a continually increasing prostate-specific antigen level, withdrawal of 10 daily doses of a supplement containing 500 $\mu \mathrm{g}$ of vitamin $B_{12}$ as cyanocobalamin, as well as $400 \mu \mathrm{g}$ of folic acid as pteroylglutamic acid and $400 \mu \mathrm{g}$ of L-5methyltetrahydrofolate for a combined total of $800 \mu \mathrm{g}$ of mixed folates, was associated with a return to a normal serum prostatic-specific antigen level.
\end{abstract}

Conclusion: This case report illustrates the importance of the effects of supplements containing large amounts of folic acid, L-5-methyltetrahydrofolate, and cyanocobalamin on the metabolism of prostate cancer cells directly and/ or B vitamin interference with docetaxel efficacy. Physicians caring for patients with prostate cancer undergoing watchful waiting, hormone therapy, and/or chemotherapy should consider the possible acceleration of tumor growth and/or metastasis and the development of drug resistance associated with supplement ingestion. We describe several pathways of metabolic and epigenetic interactions that could affect the observed changes in serum levels of prostate-specific antigen.

\section{Introduction}

The clinical course of our patient with hormone-refractory or hormone-resistant prostate cancer appears to have been affected by ingestion followed by withdrawal of a vitamin supplement containing a mixture of large amounts of folic acid (FA), L-methyltetrahydrofolate (Lmethyl-THF, or folate) and cyanocobalamin (vitamin $B_{12}$ ). Prior to supplement withdrawal, the patient had been treated with docetaxel for 18 weeks but had a

\footnotetext{
* Correspondence: glennmd@gmail.com
Whittier Cancer Research Building, 13025 Bailey Street, Whittier, CA 90601,

* Correspondence: glennmd@gmail.com
Whittier Cancer Research Building, 13025 Bailey Street, Whittier, CA 90601, USA
}

(c) 2011 Tisman and Garcia; licensee BioMed Central Ltd. This is an Open Access article distributed under the terms of the Creative Commons Attribution License (http://creativecommons.org/licenses/by/2.0), which permits unrestricted use, distribution, and reproduction in any medium, provided the original work is properly cited. continuous rise in serum prostatic-specific antigen (PSA) levels. Only after withdrawal of the supplement did the patient's elevated serum PSA level return to normal (from $22 \mathrm{ng} / \mathrm{mL}$ to $2.08 \mathrm{ng} / \mathrm{mL}$ ).

\section{Biological and clinical background}

In 1946, Lewisohn et al. [1] reported the effects of pteroylglutamic acid (teropterin) and FA (defined as liver Lactobacillus casei factor) on mice with spontaneous breast cancer. Careful examination of their results revealed that the newly discovered FA stimulated, in a dose-dependent fashion, the growth and metastasis of spontaneous murine breast tumors and shortened 
overall survival. Two years later Heinle and Welch [2] reported FA stimulation of chronic myelogenous leukemia (CML) in three patients so inflicted. In 1948, Farber [3] referred to an "acceleration phenomenon" observed while treating 10 children with leukemia with pteroylglutamic acid (diopterin) and teropterin. In 1950, Skipper et al. [4] reported that large doses of FA alone and in combination with aminopterin modulated the survival of mice with the transplanted acute Ak4 strain of leukemia. He surmised that FA is a rate-controlling factor in Ak4 leukemia. An excess of FA clearly accelerated the leukemic process, causing the animals to die before untreated controls. Acceleration of CML by vitamin $B_{12}$ in patients with pernicious anemia was reported by Corcino et al. in 1971 [5] and Green in 1994 [6]. In 2009, Tisman et al. [7] presented evidence for the acceleration of prostate cancer dedifferentiation during vitamin $B_{12}$ depletion and prostate cancer acceleration in response to vitamin $B_{12}$ administration in a patient with localized prostate cancer and pernicious anemia. In 2009, Figueiredo et al. [8] reported the results of a large, randomized, controlled clinical trial carried out over 10 years in which a group of men received $1000 \mu \mathrm{g}$ of oral FA daily. They observed a near tripling of the incidence of prostate cancer compared to controls. Finally, a report by Lawson et al. [9] published in 2007 described a direct relationship between prostate cancer stage and multivitamin use. During that period, most multivitamins contained an additional $400 \mu \mathrm{g}$ of FA.

\section{Case presentation}

Our patient is a 71-year-old Caucasian man who had been diagnosed in 1997 with prostate cancer. His baseline PSA level was $8 \mathrm{ng} / \mathrm{mL}$. All six biopsy cores contained $90 \%$ Gleason scores of 3+4 $=7$ adenocarcinoma, and peri-neural invasion was observed. The patient's clinical stage was T1c. He elected therapy with intermittent androgen deprivation (IAD) with flutamide, leuprolide, and finasteride. In 2007, after the third cycle of IAD, his PSA level slowly increased into the $3 \mathrm{ng} / \mathrm{mL}$ range and his serum testosterone remained $<20 \mathrm{ng} / \mathrm{dl}$. Sequential anti-androgen withdrawal, ketoconazole, diethylstilbestrol, estramustine, and transdermal $\beta$-estradiol, along with a trial of low-dose oral cyclophosphamide and capecitabine, all while he was being treated with leuprolide maintenance therapy, were either transiently effective or unsuccessful.

The patient was restaged, with a bone scan and computed tomography yielding only evidence of biochemical PSA relapse. He then received docetaxel $30 \mathrm{mg} / \mathrm{m}^{2}$ for three of every four weeks while his leuprolide treatment was continued. His PSA level continued to rise exponentially for 18 weeks, thus we assumed docetaxel resistance. The patient revealed that he was ingesting a supplement of 10 daily dose units of Intrinsi $\mathrm{B}_{12} /$ folate (Metagenics, San Clemente, CA, USA. Each dose unit contained $20 \mathrm{mg}$ of porcine intrinsic factor and $500 \mu \mathrm{g}$ of vitamin $\mathrm{B}_{12}$, as well as $400 \mu \mathrm{g}$ of FA, and $400 \mu \mathrm{g}$ of L-5-methyltetrahydrofolate (for a total of $800 \mu \mathrm{g}$ of mixed FAs). On 11 February 2010, his PSA level reached $21.3 \mathrm{ng} / \mathrm{mL}$, and on 25 February 2010, his serum FA level was assayed to be $134 \mathrm{ng} / \mathrm{mL}$ (normal range $5 \mathrm{ng} /$ $\mathrm{mL}$ to $24 \mathrm{ng} / \mathrm{mL}$ ), his serum vitamin $B_{12}$ level was > $1500 \mathrm{pg} / \mathrm{mL}$ (normal range $300 \mathrm{pg} / \mathrm{mL}$ to $900 \mathrm{pg} / \mathrm{mL}$ ), his serum testosterone level was $<20 \mathrm{ng} / \mathrm{mL}$ (normal range $212 \mathrm{ng} / \mathrm{mL}$ to $755 \mathrm{ng} / \mathrm{mL}$ ), and his total serum homocysteine was $12.0 \mu \mathrm{mol} / \mathrm{L}$ (normal range $7 \mu \mathrm{mol} / \mathrm{L}$ to $12 \mu \mathrm{mol} / \mathrm{L}$ ).

The patient discontinued the oral supplement on day 900 (Figure 1), and within two weeks his serum PSA level started to decline. At the time of this writing, his PSA level is $2.08 \mathrm{ng} / \mathrm{mL}$. He continues to receive weekly docetaxel chemotherapy. His last serum FA level was $4.0 \mathrm{ng} / \mathrm{mL}$ (borderline deficient), his serum vitamin $B_{12}$ level was $377 \mathrm{pg} / \mathrm{mL}$, and his total serum homocysteine level was $17.8 \mu \mathrm{mol} / \mathrm{L}$.

\section{Discussion}

High-dose folate, FA, and vitamin $\mathrm{B}_{12}$ metabolic interactions may have modulated this patient's response to PSA treatment. Figure 2 summarizes folate and B vitamin biochemistry as they relate to the de novo and salvage pathways of DNA-thymine (DNA-T) and epigenetic regulatory effects of $\mathrm{CH} 3$ group transfer to the universal methylator $S$-adenosylmethionine (SAM) by FA and its vitamers.

\section{Some metabolic consequences of high-dose FA}

Figure 2 illustrates the "untrapping" of L-methyl-THF by vitamin $B_{12}$. This untrapping regenerates active reduced folate as tetrahydrofolate (THF). DNA-T formation is dependent on 5,10-methylene-THF, which passes its $\mathrm{CH} 3$ group to deoxyuridine monophosphate, thus forming thymidine monophosphate (TMP). TMP is subsequently phosphorylated, forming thymidine triphosphate, which is incorporated into DNA as DNA$\mathrm{T}$. In the absence of adequately reduced folates, uracil rather than thymine is incorporated into DNA, thus affecting DNA and its synthesis. Incorporated uracil leads to gene point mutations and may initiate malignant transformation. FA interference of dihydrofolate reductase (DFR) and polymorphisms of methyltetrahydrofolate reductase L-methyl-THF (MTHFR), that is, MTHFR 667TT, inhibits generation of 5-methyltetrahydrofolate reductase (5-methyl-THF). Pyridoxine (vitamin $B_{6}$ ) exerts its influence in part through serine hydroxymethyltransferase (SHMT), the activity of which directs 5,10-methylene-THF in the direction of the de novo 


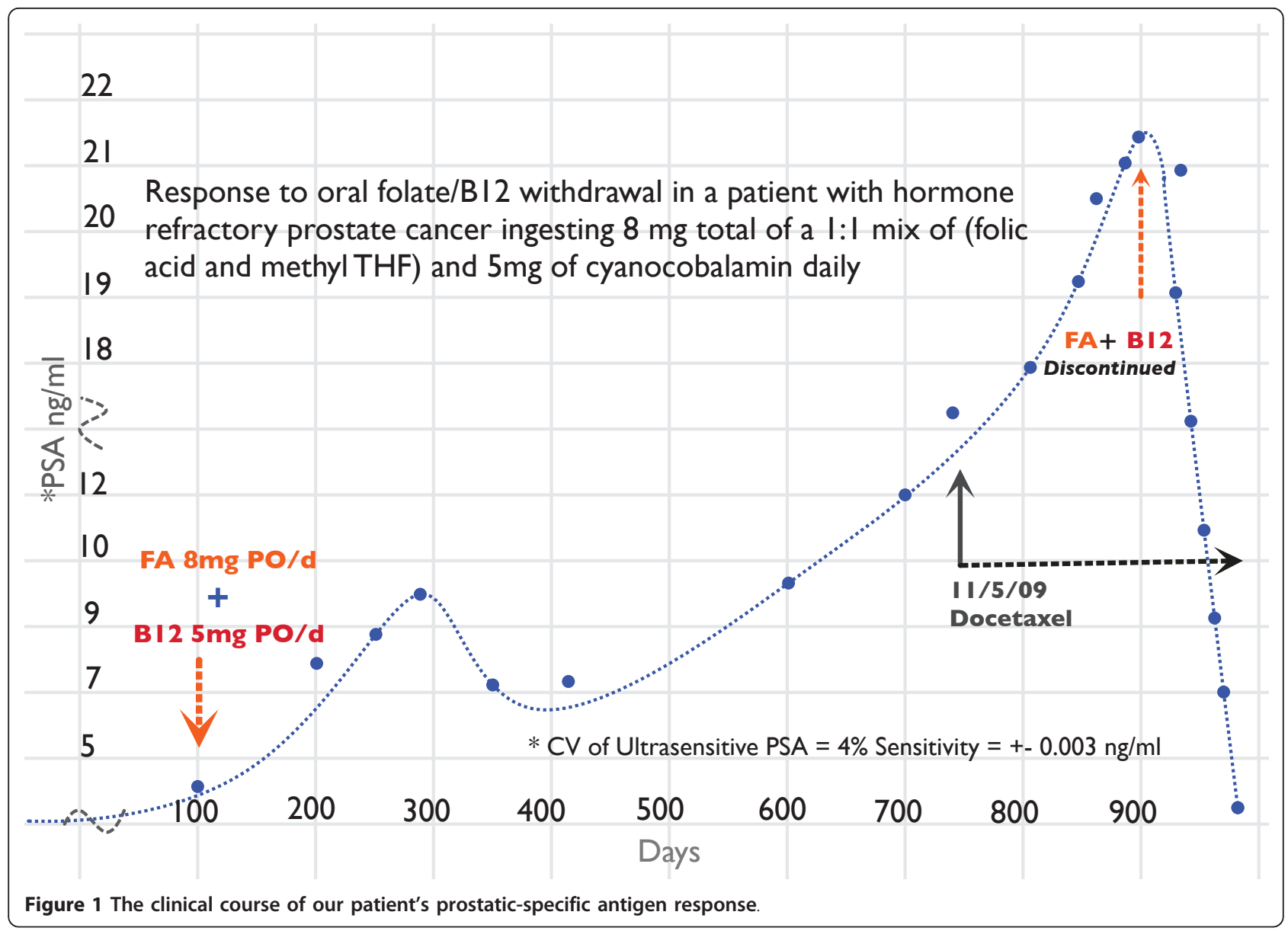

synthesis of DNA-T, thus minimizing the misincorporation of uracil into DNA.

FA is not naturally found in nature. In 1998, the US government mandated that the food supply be fortified with FA in an attempt to prevent neural tube birth defects. This action was associated with a tripling of the median normal serum folate level. However, FA has 3000-fold less affinity for DFR compared to dihydrofolate (DHF) [10], and its presence in high concentrations may induce steric interference, thus thwarting the reduction of natural DHF to THF and limiting the supply of reduced folates. In the USA, eating a normal diet while ingesting a multivitamin such as Centrum Silver (Pfizer Consumer Healthcare, Madison, NJ USA) is commonly associated with hypervitaminosis of FA to levels demonstrated to be associated with unnatural circulating levels of FA. In our practice, new patient serum folate levels usually exceed $25 \mathrm{ng} / \mathrm{mL}$ and are occasionally $>100 \mathrm{ng} / \mathrm{mL}$. Ingestion of large amounts of FA affects the intra-cellular mix of folate vitamers from methyl-THF to non-methyl-THF [11,12]. Lucock and Yates [12] and others have proposed that the intra-cellular balance between the use of methylene-THF for
DNA-T rather than for methionine synthesis may depend on the presence of both the MTHFR 677T polymorphism and high serum levels of FA. They noted that prolonged administration of large doses of FA is associated with greater reductions in intra-cellular concentrations of methylene, methenyl, formyl, and unsubstituted folate, while generation of vitamin $\mathrm{B}_{12}$ dependent, MTHFR-catalyzed methyl-THF levels decreased (Figure 2). The biological consequences of such a shift have not been thoroughly studied.

Other important metabolic interactions demonstrated by Smulders et al. [13] involving vitamin $\mathrm{B}_{12}$ and reduced folates included the folate and vitamin $\mathrm{B}_{12}$ dependence of the conversion of homocysteine to methionine minimizing toxic homocysteine while generating the universal methylator/epimethylator SAM. Changes in the SAM/S-adenosylhomocysteine (SAM/ $\mathrm{SAH})$ ratio due to changes in FA/folate concentrations, as well as the presence of hypersufficiency or insufficiency of vitamin $B_{12}$, vitamin $B_{6}$, and riboflavin (vitamin $\mathrm{B}_{2}$ ), may modulate the activity of folate vitamers. MTHFR and its many polymorphisms have profound effects as well $[14,15]$. High doses of both 


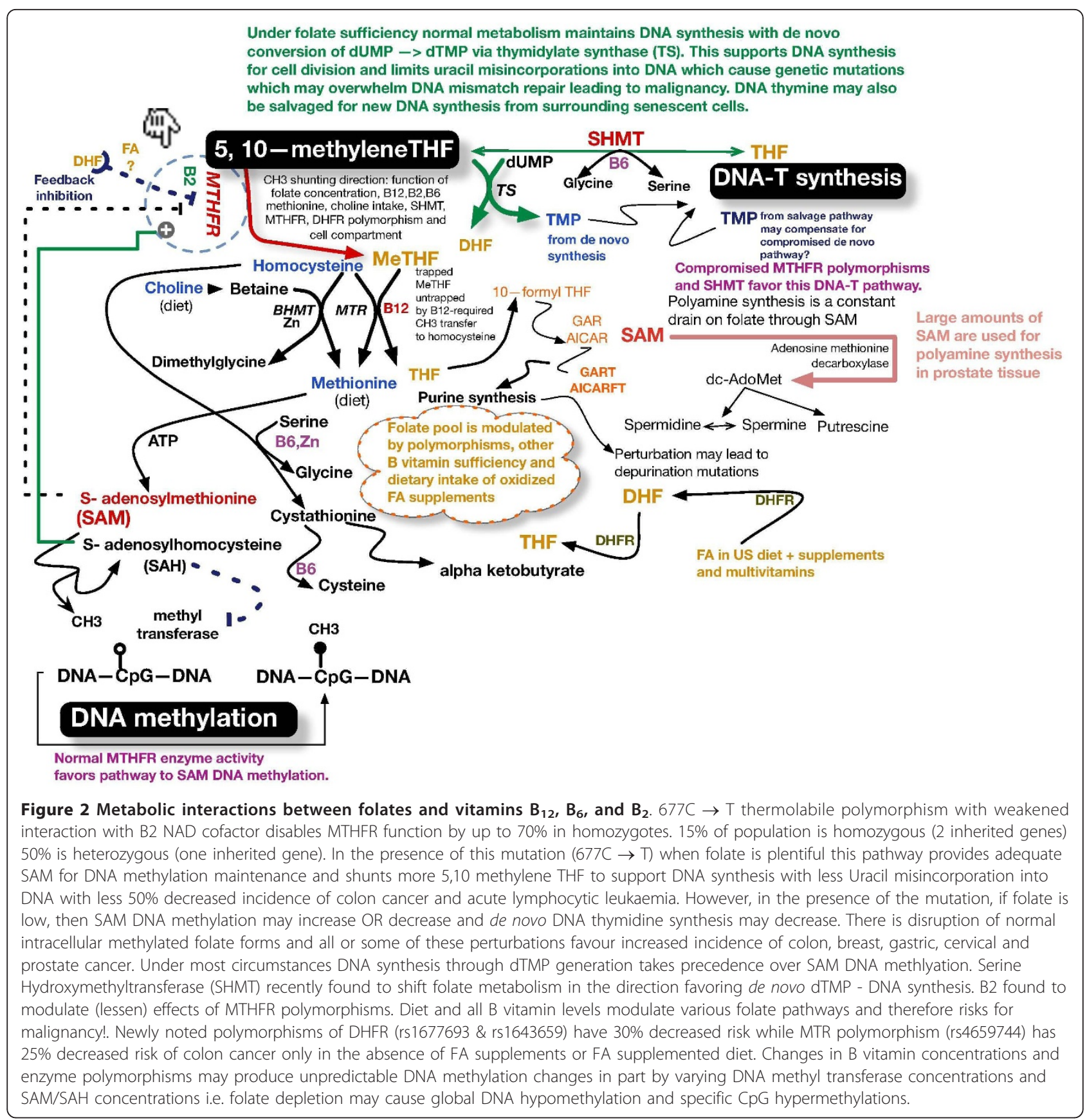

vitamin $B_{2}$ and folates enhance the binding of the MTHFR co-factor flavin adenine dinucleotide (FAD) to MTHFR and its MTHFR 677T polymorphism. This FAD co-factor binding is weakened in the MTHFR (TT) and MTHFR (CT) polymorphisms, producing $60 \%$ and $30 \%$ less efficient heat-labile enzymes, respectively. The heterozygous MTHFR (CT) is present in about $40 \%$ of the US population, while two copies of the MTHFR (TT) allele are present in about $10 \%$ of the US population.
The concentrations of B vitamins and the presence of various coenzyme polymorphisms eventually affect gene expression and tumor behavior. Collin et al. found that higher serum folate levels are associated with increased risk [16] and faster progression [17] of localized prostate cancer.

\section{FA and epigenetic modifications in prostate cancer}

The link between heritable epimethylation of cytosine bases within promoter cytosine-phosphate-guanosine 
(CpG) islands and cancer initiation, promotion, and progression is well established $[18,19]$. Its relevance to the genesis of prostate cancer is illustrated by methylation of the glutathione $S$-transferase (GSTP1) gene. Epimethylation of the GSTP1 gene is absent in normal prostate tissue and present in $6.4 \%$ of proliferative inflammatory atrophy, which is the precursor lesion of prostate cancer. GSTP1 hypermethylation is observed in $70 \%$ of patients with high-grade prostatic intra-epithelial neoplasia (a marker lesion associated with the subsequent development of prostate cancer) and in $90 \%$ of patients with prostate cancer [20].

In 2009, Figueiredo et al. [8] reported the results of administering $1000 \mu \mathrm{g}$ of FA as a supplement to 327 men compared to 316 controls for approximately 10 years. Their controlled clinical study revealed an almost threefold higher incidence of prostate cancer in the group that received FA supplements ( 25 vs. 9 patients; $P$ $=0.007$ (logrank test) with an age-adjusted hazard ratio of 2.63). Hultdin et al. [21], in a study conducted in Sweden, observed that vitamin $B_{12}$ supplementation was associated with an up to threefold increase in the risk of prostate cancer.

Yegnasubramanian et al. [22] noted that global DNA hypomethylation occurs later than CpG island hypermethylation in prostate carcinogenesis. These changes occur during prostate cancer progression and metastatic dissemination. Thus, DNA methylation may be responsible not only for carcinogenesis but also for tumor dedifferentiation as well as destabilizing genetic mutations, leading to tumor stimulation and metastasis. Collin et al. $[16,17]$ found that two folate pathway polymorphisms (MTR 2756A > G and SHMT1 1420C > T) and circulating concentrations of vitamin $B_{12}$ were associated with an increased risk of prostate cancer. Bistulfi et al. [23] demonstrated that prostate cells are highly susceptible to genetic and epigenetic changes caused by mild folate depletion.

E-cadherin, a transmembrane glycoprotein and a member of the cadherin family of cell adhesion molecules, mediates cell-cell adhesion via calcium-dependent interactions. E-cadherin, which may function as a tumor suppressor gene in tumor invasion and metastasis, is decreased or absent in many cancers and is predictive of tumor progression and poor patient outcome. In prostate cancer, decreased expression of E-cadherin correlates with hypermethylation of its promoter in patients' samples and human cell lines as well [24]. Pellis et al. [25] noted that incubation in the presence of high levels of FA $(100 \mathrm{ng} / \mathrm{mL})$ is associated with a marked decrease in E-cadherin expression in colon cancer cells in vitro [25].

As discussed above with regard to our patient, numerous possible $\mathrm{FA}$ and vitamin $\mathrm{B}_{12}$ pathways may have modulated prostate tumor growth. Ours is not the first patient with prostate cancer in whom we observed a response to a $\mathrm{B}$ vitamin [7]. We believe that the changes in PSA observed in our patient may have been related to changes in his serum levels of folate and/or vitamin $\mathrm{B}_{12}$.

Docetaxel therapy was deemed ineffective because of the absence of a PSA response during 18 weeks of administration. However, because the PSA decline occurred after withdrawal of B vitamins during docetaxel administration, the drug was continued for fear that there was a possible unknown relationship between it and the B vitamins. A search of the literature did not support a direct metabolic interaction between docetaxel or other taxanes and B vitamers; however, there is support for mediation of chemotherapy resistance to many drugs, including docetaxel, via DNA epimethylation [26-28]. We therefore consider the reversal of docetaxel resistance by folate/vitamin $B_{12}$-mediated changes in DNA epimethylation to be possible. It is for this reason that our patient continues to receive docetaxel on the original schedule.

\section{Testosterone and folate metabolism}

In the rat, castration caused marked changes in the content and distribution of various folate coenzymes in prostate tissue, which were reversed by testosterone replacement [29]. Castration caused suppression of the activity of prostatic DHF reductase (DHFR), a major rate-limiting enzyme, as well as 10-formyl-THF synthase and SHMT. Cytoplasmic SHMT acts in concert with vitamin $\mathrm{B}_{6}$ as a metabolic switch with at least three functions (Figure 2): (1) it preferentially supplies onecarbon units for DNA-thymidylate synthesis by favoring the conversion of glycine to serine, (2) it lowers methylene-THF used for SAM synthesis by preferring serine synthesis, and (3) it essentially sequesters 5-methylTHF, thus sacrificing SAM synthesis [30]. The administration of testosterone restored the enzymatic activities to close to normal values. First described by Rovinetti et al. in 1972 [29], these castration-related changes, if present in human prostate tissue, could produce powerful metabolic and genetic changes modulated by the testosterone level of the patient.

There are several metabolic inter-relationships between FA and its vitamers aimed at the shuttling of methyl (CH3-) groups to support the synthesis of DNAthymine and to deliver methyl groups to the universal methylator SAM. The other $B$ vitamins, $B_{2}, B_{6}$, and $B_{12}$ plus methionine, a diet-supplied amino acid, as well as choline (eventually metabolized to methyl groups), support methyl group generation and folate metabolism. SAM delivers the methyl groups responsible for promoter CpG islands and global DNA cytosine 
epimethylation. Epimethylation of a gene promoter region switches off transcription of the gene's exon(s). Exon transcription yields mRNA synthesis which will eventually lead to synthesis of regulatory proteins/ enzymes.

\section{Conclusion}

Our patient's clinical course suggests that high doses of $\mathrm{B}$ vitamins ( $\mathrm{FA} /$ folate and vitamin $\mathrm{B}_{12}$ ) may modulate the course of PSA failure in castrate-resistant/refractory prostate cancer. Our patient's ingestion of large amounts of $\mathrm{FA} /$ folate and vitamin $\mathrm{B}_{12}$ was associated with PSA acceleration, while withdrawal of the supplements was associated with a significant PSA decline. Whether this result was secondary to the perturbation of the outlined metabolic interactions of B vitamers (Figure 2), due to DNA epimethylation with associated changes in gene expression, or due to other factors is unknown. The hypothesis of a yet to be discovered interaction with docetaxel is entertained as well. Studies of patient use of health store supplements, many of which are known to affect DNA metabolism and DNA methylation markers, have revealed that up to $50 \%$ of cancer patients ingest large doses of vitamins and other supplements, such as probiotics, which contain "safe" bacteria that generate copious amounts of folates within the bowel. A recent study in our clinic revealed that a majority of cancer patients present with hypervitaminosis or hypovitaminosis of at least one or more of the B vitamins noted in Figure 2. As we have discussed herein, castration, drugs, diet, vitamin supplements, and probiotics may modulate tumor cell metabolism as well as gene expression by epimethylation and synthesis of DNA. We are concerned about the finding that many gas stations and liquor stores in the USA sell so-called "quick energy" liquid supplements that contain large amounts of $B$ vitamins, including vitamins $B_{6}$ and $B_{12}$ and FA.

\section{Patient's perspective}

"I was alarmed to see a steady increase in my PSA while undergoing chemotherapy. I had been taking a dietary supplement containing large amounts of vitamin $B_{12}$ and folate. When I learned of the relationship of large amounts of folate to increasing PSA, I immediately stopped taking the supplement. My wife and I searched the Internet to find foods that were low in natural folate, and avoided those foods high in folate. When I found out the government had mandated the addition of folic acid to basically all products containing flour and grains since 1998 I was surprised and dismayed. We quickly learned to read the food content labels on packaging, and found that many foods contained folic acid. Avoiding folic acid supplemented foods meant that nearly all baked goods, cereals, crackers, pasta, egg noodles, stuffing mix, white rice, bagels, flour tortillas, sandwiches, burger rolls, dinner rolls, doughnuts, pizza, pies and cakes were off limits. My wife, who loves to bake, found organic flour that was not supplemented, and used that exclusively to make bread, cookies, pies, cakes, pizza dough, etc. Happily, doing something as simple as reducing FA intake, allowed the chemotherapy to rapidly reduce my PSA to the lowest level in years."

\section{Consent}

Written informed consent was obtained from the patient for publication of this case report and any accompanying images. A copy of the written consent is available for review by the Editor-in-Chief of this journal.

\section{Acknowledgements}

Mercideta Ramos was instrumental in the laboratory measurement of PSA, folate, vitamin $B_{12}$, and total homocysteine levels. All funding was provided by GT.

\section{Authors' contributions}

GT and AG analyzed and interpreted the data regarding the patient's clinical course, therapy, ingested supplements, and laboratory vitamer and PSA response. GT was a major contributor to the writing of the manuscript. Both authors read and approved the final manuscript.

\section{Competing interests}

The authors declare that they have no competing interests.

Received: 10 December 2010 Accepted: 25 August 2011

Published: 25 August 2011

\section{References}

1. Lewisohn R, Leuchtenberger C, Leuchtenberger R, Keresztesy JC: The influence of liver $L$. casei factor on spontaneous breast cancer in mice. Science 1946, 104:436-437.

2. Heinle R, Welch AD: Experiments with pteroylglutamic acid and pteroylglutamic acid deficiency in human leukemia. J Clin Invest 1948, 27:539.

3. Farber S, Diamond LK, Mercer RD, Sylvester RF, Wolff JA: Temporary remissions in acute leukemia in children produced by folic acid antagonist, 4-aminopteroyl-glutamic acid (aminopterin). N Engl J Med 1948, 238:787-793.

4. Skipper HE, Chapman JB, Bell M: Studies on the role of folic acid in the leukemic process. Cancer 1950, 3:871-873.

5. Corcino JJ, Zalusky R, Greenberg M, Herbert V: Coexistence of pernicious anaemia and chronic myeloid leukaemia: an experiment of nature involving vitamin $B_{12}$ metabolism. Br J Haematol 1971, 20:511-520.

6. Green R: Typical and atypical features of pernicious anemia. In Thomas Addison and His Diseases. Volume 1. Edited by: Besser M, Bhatt R, James VHT, Keen H. Bristol: Society for Endocrinology and The Thomas Addison Society; 1994:377-390.

7. Tisman G, Kutik S, Rainville C: Coexistence of pernicious anemia and prostate cancer: 'an experiment of nature' involving vitamin $B_{12}$ modulation of prostate cancer growth and metabolism: a case report. J Med Case Reports 2009, 3:9295.

8. Figueiredo JC, Grau MV, Haile RW, Sandler RS, Summers RW, Bresalier RS, Burke CA, McKeown-Eyssen GE, Baron JA: Folic acid and risk of prostate cancer: results from a randomized clinical trial. J Natl Cancer Inst 2009, 101:432-435.

9. Lawson KA, Wright ME, Subar A, Mouw T, Hollenbeck A, Schatzkin A, Leitzmann MF: Multivitamin use and risk of prostate cancer in the National Institutes of Health-AARP Diet and Health Study. I Natl Cancer Inst 2007, 99:754-764. 
10. Bailey SW, Ayling JE: The extremely slow and variable activity of dihydrofolate reductase in human liver and its implications for high folic acid intake. Proc Natl Acad Sci USA 2009, 106:15424-15429.

11. Smulders YM, Smith DE, Kok RM, Teerlink T, Gellekink H, Vaes WH, Stehouwer CD, Jakobs C: Red blood cell folate vitamer distribution in healthy subjects is determined by the methylenetetrahydrofolate reductase C677T polymorphism and by the total folate status. I Nutr Biochem 2007, 18:693-699.

12. Lucock M, Yates Z: Folic acid: vitamin and panacea or genetic time bomb? Nat Rev Genet 2005, 6:235-240.

13. Smulders YM, Smith DE, Kok RM, Teerlink T, Swinkels DW, Stehouwer CD, Jakobs C: Cellular folate vitamer distribution during and after correction of vitamin $B_{12}$ deficiency: a case for the methylfolate trap. Br J Haematol 2006, 132:623-629

14. Fenech M: The Genome Health Clinic and Genome Health Nutrigenomics concepts: diagnosis and nutritional treatment of genome and epigenome damage on an individual basis. Mutagenesis 2005, 20:255-269.

15. Fenech MF: Dietary reference values of individual micronutrients and nutriomes for genome damage prevention: current status and a road map to the future. Am J Clin Nutr 2010, 91:1438S-1454S.

16. Collin SM, Metcalfe C, Refsum H, Lewis SJ, Zuccolo L, Smith GD, Chen L, Harris R, Davis M, Marsden G, Johnston C, Lane JA, Ebbing M, Bønaa KH, Nygård O, Ueland PM, Grau MV, Baron JA, Donovan JL, Neal DE, Hamdy FC, Smith AD, Martin RM: Circulating folate, vitamin $B_{12}$, homocysteine, vitamin $B_{12}$ transport proteins, and risk of prostate cancer: a casecontrol study, systematic review, and meta-analysis. Cancer Epidemiol Biomarkers Prev 2010, 19:1632-1642.

17. Collin SM, Metcalfe C, Refsum H, Lewis SJ, Smith GD, Cox A, Davis M, Marsden G, Johnston C, Lane JA, Donovan JL, Neal DE, Hamdy FC, Smith AD, Martin RM: Associations of folate, vitamin $B_{12}$, homocysteine, and folate-pathway polymorphisms with prostate-specific antigen velocity in men with localized prostate cancer. Cancer Epidemiol Biomarkers Prev 2010, 19:2833-2838.

18. Davis $C D$, Uthus EO: DNA methylation, cancer susceptibility, and nutrient interactions. Exp Biol Med (Maywood) 2004, 229:988-995.

19. Ellis L, Atadja PW, Johnstone RW: Epigenetics in cancer: targeting chromatin modifications. Mol Cancer Ther 2009, 8:1409-1420.

20. Enokida H, Shiina H, Urakami S, Igawa M, Ogishima T, Li LC, Kawahara M, Nakagawa M, Kane CJ, Carroll PR, Dahiya R: Multigene methylation analysis for detection and staging of prostate cancer. Clin Cancer Res 2005, 11:6582-6588.

21. Hultdin J, Van Guelpen B, Bergh A, Hallmans G, Stattin P: Plasma folate, vitamin $B_{12}$, and homocysteine and prostate cancer risk: a prospective study. Int J Cancer 2005, 113:819-824.

22. Yegnasubramanian S, Haffner MC, Zhang Y, Gurel B, Cornish TC, Wu Z, Irizarry RA, Morgan J, Hicks J, DeWeese TL, Isaacs WB, Bova GS, De Marzo AM, Nelson WG: DNA hypomethylation arises later in prostate cancer progression than $\mathrm{CpG}$ island hypermethylation and contributes to metastatic tumor heterogeneity. Cancer Res 2008, 68:8954-8967.

23. Bistulfi G, VanDette E, Matsui SI, Smiraglia D: Mild folate deficiency induces genetic and epigenetic instability and phenotype changes in prostate cancer cells. BMC Biol 2010, 8:6.

24. Diaw L, Woodson K, Gillespie JW: Prostate cancer epigenetics: a review on gene regulation. Gene Regul Syst Bio 2007, 1:313-325.

25. Pellis L, Dommels Y, Venema D, Polanen A, Lips E, Baykus H, Kok F, Kampman E, Keijer J: High folic acid increases cell turnover and lowers differentiation and iron content in human HT29 colon cancer cells. Br J Nutr 2008, 99:703-708.

26. Kastl L, Brown I, Schofield AC: Altered DNA methylation is associated with docetaxel resistance in human breast cancer cells. Int J Oncol 2010, 36:1235-1241.

27. Segura-Pacheco B, Perez-Cardenas E, Taja-Chayeb L, Chavez-Blanco A, Revilla-Vazquez A, Benitez-Bribiesca L, Duenas-González A: Global DNA hypermethylation-associated cancer chemotherapy resistance and its reversion with the demethylating agent hydralazine. J Transl Med 2006, 4:32.

28. Ibrahim M: Perspective of DNA methylation in cancer research. Int $J$ Cancer Res 2010, 6:188-201.
29. Rovinetti C, Bovina C, Tolomelli B, Marchettie M: Effects of testosterone on the metabolism of folate coenzymes in the rat. Biochem J 1972, 126:291-294.

30. Herbig K, Chiang EP, Lee LR, Hills J, Shane B, Stover PJ: Cytoplasmic serine hydroxymethyltransferase mediates competition between folatedependent deoxyribonucleotide and S-adenosylmethionine biosyntheses. J Biol Chem 2002, 277:38381-38389.

doi:10.1186/1752-1947-5-413

Cite this article as: Tisman and Garcia: Control of prostate cancer associated with withdrawal of a supplement containing folic acid, Lmethyltetrahydrofolate and vitamin $\mathrm{B}_{12}$ : a case report. Journal of Medical Case Reports 2011 5:413.

\section{Submit your next manuscript to BioMed Central and take full advantage of:}

- Convenient online submission

- Thorough peer review

- No space constraints or color figure charges

- Immediate publication on acceptance

- Inclusion in PubMed, CAS, Scopus and Google Scholar

- Research which is freely available for redistribution

Submit your manuscript at www.biomedcentral.com/submit
Biomed Central 